\title{
Scleral dellen following strabismus surgery
}

\author{
Amar Pujari, Pradeep Sharma, Shabeer Basheer, Swati Phuljhele
}

Department of Ophthalmology Dr Rajendra Prasad Centre for Ophthalmic Sciences, All India Institute of Medical Sciences, New Delhi, Delhi, India

\section{Correspondence to}

Dr Amar Pujari, dramarpujari@gmail.com

Accepted 7 May 2018

\section{DESCRIPTION}

A 28-year-old male patient underwent uneventful surgery for right sensory esotropia. On postoperative day 1 , there was still residual esotropia, and the forced duction test (FDT) revealed a residual tightness of the medial rectus muscle. The patient underwent exploration under local anaesthesia; intraoperatively there were still residual adhesions, which were released to achieve a free FDT for the medial rectus without any residual deviation. Postoperatively, on day 1 , the patient was orthophoric with absence of additional complications. However, on day 7 , the patient presented with medial-sided conjunctival recession with bare sclera, along with dryness and thinning of the underlying sclera with uveal tissue exposure (figure 1A).

Under care, the patient was started on topical antibiotics (moxifloxacin hydrochloride 0.5\%) three times a day, along with frequent surface lubrication (every hour). On day 3 there was minimal response and the scleral thinning persisted, and to prevent further progression under topical anaesthesia conjunctival advancement was performed to achieve good anatomical results. After 1 week, the patient again presented with minimal conjunctival recession, but this time without any
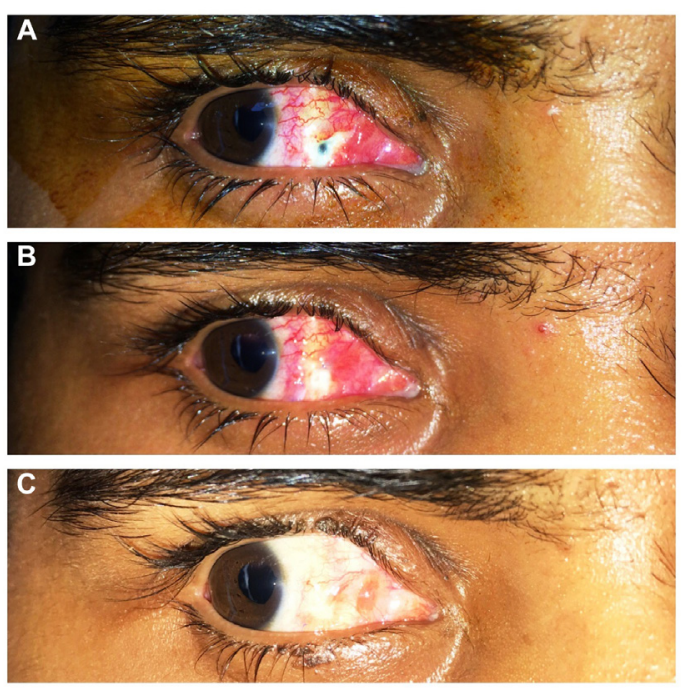

Figure 1 (A) On postoperative day 7, there were conjunctival recession, scleral thinning and underlying uveal show. (B) Seven days following conjunctival advancement, there was again minimal conjunctival recession but without any further scleral thinning or uveal exposure. (C) At the end of 3 weeks, there was complete epithelisation of the ocular surface without any additional complications, and the patient remained orthophoric. underlying scleral exposure (figure 1B). When the patient was questioned about rubbing or ocular manipulation, he revealed usage of a cotton pad to wipe the tears along the medial canthal region, with a simultaneous significant nasal drag of the conjunctiva. The patient was counselled and advised not to do the same. He was kept under follow-up with frequent surface lubrication (every 2 hours) and topical antibiotics (moxifloxacin $0.5 \%$ three times a day), and at the end of 3 weeks the congestion went down with good surface epithelisation and healing with absence of any additional complications (figure 1C).

Dellen is a localised, well-defined excavation at the margins of the cornea. Because of tear film instability, there is evaporation and dehydration of the underlying ocular surface, leading to compactness and thinning of the corneal lamella. In contrast to corneal dellen, scleral dellen is rarely noted following strabismus; however, it is frequently noted following pterygium surgery. The sclera is an opaque ocular coat with dense random arrangements of the collagen lamella. It is an avascular layer mainly deriving its nutrition from the episcleral vessels and partly from the choroidal vasculature.

Among the noted case reports, scleral dellen was seen nasally in two cases following medial rectus muscle recession ${ }^{12}$ and temporally in one case following usage of fibrin glue. ${ }^{3}$ Intraoperative risk factors for scleral exposure and dehydration include excessive use of thermal cautery especially in cases with vascular compromise and conjunctival resection. There was evident conjunctival retraction in one case. The average duration between surgery and clinical diagnosis of scleral dellen was between 3 and 7 days. ${ }^{1-3}$ These patients presented with an oval, blackish, discoloured patch over the operated site with absence of any infection/inflammation. Frequent surface lubrication with or without conjunctival advancement was sufficient to achieve closure of the defect.

\section{Learning points}

- The patient under discussion did not have any pre-existing ocular surface disorder of tear film instability, but his wrong practices led to conjunctival retraction and ocular surface dryness with scleral dellen.

- Patients undergoing strabismus surgery should be counselled about appropriate postoperative practices, and a close observation should be kept to ensure this. 
Other close differential diagnoses for scleral dellen include senile hyaline plaque due to degeneration of the superficial scleral layers with hyaline deposition and scleral thinning, which does not usually need any clinical intervention.

Contributors AP, PS, SB and SP have evaluated the case in detail, followed by surgical intervention to achieve optimal outcomes. AP, PS, SB and SP, after critically analysing the educational value of the case, wrote the report together.

Funding The authors have not declared a specific grant for this research from any funding agency in the public, commercial or not-for-profit sectors.

Competing interests None declared.

Patient consent Obtained.
Provenance and peer review Not commissioned; externally peer reviewed.

(C) BMJ Publishing Group Ltd (unless otherwise stated in the text of the article) 2018. All rights reserved. No commercial use is permitted unless otherwise expressly granted.

\section{REFERENCES}

1 Sharma P, Aryad AV, Prakash P. Scleral dellen in strabismus surgery. Acta Ophthalmol 2009:68:493-4.

2 Perez I. The "scleral dellen," a complication of adjustable strabismus surgery. J Aapos 2002;6:332-3.

3 Basmak H, Erdogan $\mathrm{H}$, Sahin A, et al. Scleral dellen after fibrin glue use in strabismus surgery. J Pediatr Ophthalmol Strabismus 2010;47:e1-3.

Copyright 2018 BMJ Publishing Group. All rights reserved. For permission to reuse any of this content visit

http://group.bmj.com/group/rights-licensing/permissions.

BMJ Case Report Fellows may re-use this article for personal use and teaching without any further permission.

Become a Fellow of BMJ Case Reports today and you can:

- Submit as many cases as you like

- Enjoy fast sympathetic peer review and rapid publication of accepted articles

Access all the published articles

Re-use any of the published material for personal use and teaching without further permission

For information on Institutional Fellowships contact consortiasales@bmjgroup.com

Visit casereports.bmi.com for more articles like this and to become a Fellow 